\title{
Narrative analysis applied to text production
}

\author{
Investigating the processes of quoting \\ in the making of a broadcast news story
}

\section{Gilles Merminod}

University of Lausanne

The following paper adopts the vantage point of a linguistic ethnographic approach to news production, focused on the process of quoting, and combined with narrative analysis. The starting point of the analysis is an account given by a person who lived through a dramatic event. The paper investigates how the processes of recontextualization affects the account during the making of a broadcast news story. It explains how and why news practitioners adjust stretches of talk to the news text they are producing, and it reveals to what extent a pre-existing version of what happened (that of the account) can be reshaped by one in the making (that of the news story in which the account is going to figure). In the case study, the processes of recontextualization relates to three narrative issues: (1) quoting involves adapting the account's characters' categorizations to those of the news story; (2) quoting entails choosing between different schemes of incidence that depict what happened slightly differently; (3) quoting asks for a delimitation of the account's spatiotemporal parameters that corresponds with those of the news story. Such a narrative adjustment is neither a tightly planned nor an arbitrary process but is embedded in the professional practice as it unfolds in the social and material world.

Keywords: quoting, newsroom, news story, recontextualization, narrative analysis, linguistic ethnography

\section{Introduction: Quoting in news settings, translation, and recontextualization}

Studies on quoting practices in news settings highlight how much texts are transformed - even manipulated - in the course of the news production processes (Haapanen, 2017, 2018). Transformations generally pertain to forms of compliance 
with professional conventions (stylebook, tacit knowledge, etc.), practical requirements (editorial space, speaking time, etc.), processes of audience design (dramatization, proximity, etc.) as well as to a lack of reflexivity on the part of journalists about what they bring to the texts they handle. These transformations also relate to the fact that quoting necessarily entails the adjustment of a preexisting discourse to an ongoing framing of the events that needs to be coherent as well as authoritative (Van Hout \& Macgilchrist, 2010, p.150). The study of quoting in news settings is necessarily the study of particular instances of recontextualization (see Introduction to this issue; Van Hout \& Jacobs, 2008; Bauman \& Briggs, 1990): selected stretches of text and talk are lifted out of their previous contexts, inserted into new emerging ones, which can be semiotic products under construction (texts, multimodal artifacts, etc.), and adjusted to them (in terms of forms and functions). In this respect, quotations in a foreign language, far from being a special case in a globalized world, are particularly interesting inasmuch as there is room for transformation during the process of translation (Davier, 2017; Davier \& Convay, 2019; Haapanen \& Perrin, 2019).

Building on a case study that sees a translation from English to French during the making of a broadcast news story, I investigate the processes of recontextualization as it affects an account given by a person who lived through a dramatic event. My analysis explains how and why news practitioners adjust the account to the news item they are producing. It reveals to what extent a pre-existing version of what happened (that of the account) can be reshaped by one in the making (that of the news item in which the account is going to figure).

\section{Data: Documenting the journalists' daily work in the newsroom}

The data was collected as part of the Idée Suisse project (Perrin, 2013) in March 2007. The project researchers were able to enter the newsrooms of three television news shows aired by the Swiss public service broadcaster, including Le Journal. Le Journal is the most widely viewed news show in the French-speaking part of Switzerland. Covering national and international news, Le Journal has two daily editions (12:45 and 19:30). The data combines research interviews (with different stakeholders from the public broadcasting service: politicians, managers, journalists), audiovisual and digital recordings of actual television news production processes (editorial meetings, computer writing processes, sequences of collaborative work featuring different news practitioners), texts (newswires and other documents used during the news production process), and multimodal artifacts (including the television news stories broadcast by the Swiss public service at the end of the production process). This data provides a unique insight into the work of journalists as it is 
carried out on a daily basis. For this contribution, I focus on a day in which an experienced journalist and a cutter deal with an aircraft crash in Indonesia and, more particularly, on the moment in the production process in which the journalist translates the account of a security guard who participated in the rescue operation.

\section{Methods: The linguistic ethnography and narrative analysis of news production}

My study draws on the tools of the linguistics of news production (Burger, 2018; Cotter, 2010; NTT, 2011; Perrin, 2013, 2018). It espouses a linguistic ethnographic approach (Rampton, Maybin, \& Roberts, 2015), which enables me to analyze the different steps through which a news story is produced and to take into account the local rationalities (Jacobs, 2017) as well as the constraints and affordances (Van Hout, 2015) relating to the news practitioners' daily work. To address the specific issues relating to the recontextualization of the account in a television news report, I adopt the vantage point of narrative analysis applied to news production (Merminod, 2018a, 2018b, 2020).

The study of narratives can be organized in three complementary poles, respectively the analysis of narrative situations, ideologies, and configurations (Merminod, 2019):

- The analysis of narrative situations considers what happens when one tells a story (who tells what to whom, where, when, how, why, and what for) and accounts for the sites, participants, and ways of telling that are involved in a narrative activity (Georgakopoulou, 2007, 2015).

- The analysis of narrative ideologies deems the cultural conceptions underlying narrative activities (what is tellable by and to whom; where, when, how, why and what for it is tellable), taking into account how social evaluations reflect on what it means to tell a story (Norrick, 2004; Thornborrow \& Coates, 2005).

- The analysis of narrative configurations deals with the semiotic representations produced when telling a story (what is told) and accounts for the chronotope(s) (the who, what, where, and when of the story), the sequence(s) of events (what has followed, follows, will follow what, how, and why) and the particular perspective(s) on the recounted or imaginary experience(s) (the 'what it is like') that may be projected by the story (Fludernik, 2009; Herman, 2009).

The analysis of narrative configurations - by distinguishing between chronotope(s), event(s), and experience(s) - turns out to be particularly helpful to study how an account is transformed through a newsmaking process. It enables us to track the variation between the different versions of the same story. 


\section{Analysis: An account in the making of a TV news story}

At the end of the production process, the account is embedded in a news story about an aircraft crash in Indonesia, broadcast during the noon edition of the French-speaking TV news bulletin. It follows a first sequence focusing on the crash survivors (see Excerpt 3), and reports on the experience of a security guard who took part in the rescue operations. The account comes from an interview filmed on-site and is dubbed in French (Excerpt 1). The original version in Indonesian is kept under the voiceover translation, even though this language is not part of the linguistic repertoire of most of the audience. Combined with the footage, Indonesian language authenticates what is said in the account, embodying it in a figure anchored in a place and a culture (Indonesia).

(1) The broadcast version of the account (TV news story, March 7, 2007, 12:47) J'ai entendu deux explosions et j'ai tiré quatre personnes hors de l'avion, saines et sauves. Une trentaine de passagers se trouvaient déjà dehors, elles aussi toutes en vie.

I heard two explosions, and I pulled four people out of the airplane, safe and sound. About thirty passengers were already outside, all of them also alive. ${ }^{1}$

The account involves two types of entities: (1) the security guard ("I"), both teller and character, in the role of the agent/rescuer and (2) a group of individuals in the role of the patients/beneficiaries of the rescue act. The first utterances articulate two successive moments: [u1] "I heard two explosions" and [u2] "and I pulled four people out of the airplane, safe and sound". In the second utterance ([u2]), the adjective group ("safe and sound") can be interpreted in two ways: either "safe and sound" only means "without any injuries" - a character's description unrelated to the rescue act being described - or "safe and sound" is seen as the result of the rescue act performed by the security guard. The third utterance establishes the circumstances surrounding the rescue act: [u3] "about thirty passengers were already outside, all of them also alive". In the account, all the human entities represented except the teller-rescuer are identified as survivors.

Even if the original language of the account is Indonesian, the practitioners work from an English translation (see Excerpt 2) and not from the original one. This reminds us that quotations are caught in complex trajectories. Stretches of talk are isolated from their interactional ecologies, written while translated to be reusable in another language and context (Haapanen, 2017; Haapanen \& Perrin, 2017).

1. The English translations carried out by the researcher are in italics. 
(2) The account in the newswire (Newswire, March 7, 2007, 04:30 a.m.) I heard two explosions and I pulled four victims out of the plane and they were safe. About 30 people were also gathered outside the plane. They were safe too.

The account's version in the news wire broadly corresponds with the broadcast version of the account (Excerpt 1). It shows a similar sequence of events (from a perilous initial state to a safe final state) as well as a comparable chronotope (a rescuer and people to rescue in the immediate space-time surroundings of the crash).

Nevertheless, it is worth noting that the English version of the account is anchored in a specific context: a news wire sent by news agencies to news organization. The account is included in a long list of shots documenting the rescue operation. It is a resource made available to news practitioners among other resources. The footage available in the wire was shot after the crash. The shots corresponds with two different spatial settings: most of them document what happened on the crash site depicting various parts of the event (the aircraft burning, security agents rescuing people, and securing the site, people watching the scene) while the remaining shots show injured people being cared for in a hospital. In the newswire, the account illustrates, with other shots, the experience of those involved in the rescue operation.

In the co(n)text of the TV news story, the account appears after a sequence focusing on the survivors, passengers, and crew (see Excerpt 3).

(3) The beginning of the news story (TV news story, March 7, 2007, 12:46-12:47) Quelques instants après le crash, la fuite éperdue, loin du Boeing, de l'un des survivants. Ce passager n'est pas encore à l'abri, mais sa caméra est enclenchée. Pas moins de cent douze voyageurs sur les cent trente-trois transportés par la compagnie indonésienne Garuda ont survécu, et six membres de l'équipage sur sept. Mais beaucoup sont blessés. Le témoignage d'un agent de sécurité de l'aéroport de Yogyakarta.

A few moments after the crash, the desperate escape, away from the Boeing, for one of the survivors. This passenger is not yet safe, but his camera is on. No fewer than one hundred and twelve passengers among the one hundred and thirtythree transported by the Indonesian company Garuda survived, and six out of seven members of the crew. But many are injured. The account of a security guard at the airport in Yogyakarta.

In such a co(n)text, the account (Excerpt 1) describes the "positive" aspect of this unfortunate event, namely an unexpected number of survivors. Rather than primarily illustrating the experience of those who took part in the rescue operation (as it was the case in the newswire), the security guard's account is used in the news report to describe the situation of those who got through the crash without being 
injured or dying. This survivor orientation is visible through the journalist's categorial work relating to the human entities other than the agent, as evidenced below. This categorial work helps him to adjust the account to the television news report.

The translation and rewriting of the account takes place mainly between 11:27 a.m. and 11:33 a.m. To do so, the journalist works in close collaboration with a cutter. Apart from slight modifications, the translation is done in five steps corresponding to the textual structure of the newswire's account (see Table 1).

Table 1. Steps of translation (March 7, 2007, 11:27-11:33 a.m.)

\begin{tabular}{|c|c|c|c|}
\hline & Newswire's version & Journalist's translation & $\begin{array}{l}\text { English translation of the } \\
\text { journalist's translation }\end{array}$ \\
\hline 1. & I heard two explosions and & j’ai entendu deux explosions et & I heard two explosions and \\
\hline 2. & $\begin{array}{l}\text { I pulled four victims out of } \\
\text { the plane }\end{array}$ & $\begin{array}{l}\text { j'ai tiré quatre personnes hors de } \\
\text { l'avion }\end{array}$ & $\begin{array}{l}\text { I pulled four persons out of } \\
\text { the plane }\end{array}$ \\
\hline 3. & and they were safe & saines et sauves & safe and sound \\
\hline 4. & $\begin{array}{l}\text { about } 30 \text { people were also } \\
\text { gathered outside the plane }\end{array}$ & $\begin{array}{l}\text { une trentaine de passagers se } \\
\text { trouvaient déjà hors de l'appareil }\end{array}$ & $\begin{array}{l}\text { about } 30 \text { passengers were } \\
\text { already out of the aircraft }\end{array}$ \\
\hline 5. & they were safe too & elles aussi toutes en vie & all of them also alive \\
\hline
\end{tabular}

In addition to showing that the journalist translates the account clause by clause, the comparison between the French and English versions highlights three major changes:

- the systematic change in the categorization of the human entities rescued by the security guard ("victims" becomes "personnes (persons)"and "people" becomes "passagers (passengers)"), which evidences a homogenization of the reported experience;

- the transformation of attributive structures ("they were safe" and "they were safe too") into extrapositions ("saines et sauves (safe and sound)" and "elles aussi toutes en vie (all of them also alive)"), which shows a weakening of the events' sequencing;

- the modification of the last reported event's description (by replacing "were also gathered" by "se trouvaient déjà (were already)"), which indicates a compression of the world depicted in the narrative (i.e., the tale world) in favor of the sole representation of the immediate consequences of the accident.

Far from being the journalist's sole responsibility, the adjustment of the account is done in interaction with the cutter. Because translation brings out some uncertainties about the meaning of the words and the text, it leads news practitioners to suggest different interpretations of the same account. 


\subsection{Consistency through the homogenization of experience}

Of particular interest are the categorizations of the persons being rescued. The characters' categorization in the broadcast account (Excerpt 1 ) is in congruence with the characters' categorization featuring at the beginning of the TV news story (Excerpt 3). In fact, the process of recontextualization has adjusted the security guard's account to the journalist's perspective and contributes to the consistency of the news story.

Earlier that morning, the journalist and the cutter discussed in depth how to describe the individual fleeing from the plane at the beginning of the TV news story (see Excerpt 3). Two sets of characters' categorization emerged from their discussions: the first one relating to the accident and involving surviving, injured, and dead persons; the second one relating to transportation and featuring passengers, crew members, etc. These two sets of categorizations were particularly relevant to report the transformative dynamics of an aircraft disaster, inevitably departing from the expected course of events (Merminod \& Burger, 2020).

In the newswire (Excerpt 2), the categorizations are first "victims" and then "people" while the broadcast account (Excerpt 1) uses first "personnes (persons)" and then "passagers (passengers)". This change in the characters' categorization fully contributes to the adjustment of the account to the story. They result from the work of the journalist $(\mathrm{J})$ and the cutter $(\mathrm{C})$ in the cutting-room (see Excerpt 4 ).

(4) Characters' categorization ${ }^{2}$

(March 7, 2007, 11:27-11:28 a.m.)

\begin{tabular}{|c|c|c|}
\hline 17 & $\mathrm{~J}$ & .h $* I$ pull I pull four victims out of the plane* \\
\hline 18 & & $\begin{array}{l}\text { j'ai poussé quatre personnes hors de l'avion/ } \\
\text { I pushed four persons out of the plane/ }\end{array}$ \\
\hline 19 & & $\begin{array}{l}\text { parce qu'on va pas dire victimes/ puisque } \\
\text { because we're not gonna say victims/ since }\end{array}$ \\
\hline 20 & & $\begin{array}{l}\text {.h j'ai poussé quatre su[rvivants } \\
. h \text { I pushed four su[rvivors }\end{array}$ \\
\hline 21 & C & $\begin{array}{l}{[j \text { 'ai tiré }} \\
{[I \text { pulled }}\end{array}$ \\
\hline 22 & & $()$. \\
\hline 23 & C & $\begin{array}{l}\text { j'ai tiré hein } \\
\text { I pulled isn't it }\end{array}$ \\
\hline 24 & & (1) \\
\hline
\end{tabular}

2. Next transcriptions are based on the following conventions:

八 rising/ falling $\backslash$ intonational shift [ overlapping

(.) micropause (max. 0.3 )

(..) pause (min. 0.3 - max. o.6)

(n) pause in seconds

- truncation

: phonic lengthening

$=$ immediate linking

h salient breathing

\& turn extension after an overlap

txt text written by the journalist

(( )) multimodal description

${ }^{\star}$ word $^{\star}$ text being read by the journalist ita English translation

The speaker's name is indicated on the left. The numbers on the left refer to the transcribed lines. 
Lines 17 to 19 show a long turn at talk. The journalist first reads the newswire text in English and suggests a translation. He then comments his choice not to translate "victimes" as "victims," without giving an explicit reason for his choice. Nevertheless, he underlines the inadequacy of such a categorization. By using "puisque (since)," he displays his stance as a self-evident truth (Riegel, Pellat, \& Rioul, 2014, p.1055). If "victimes (victims)" is not appropriate, it is probably because it is potentially ambiguous. Such an expression can refer to a person who has been the victim of an unfortunate event (e.g., "the victims of an accident"). It can also refer to a deceased person (e.g., "the accident caused 21 victims"), in which case "victime (victim)" contrasts with "survivant (survivor)".

In the television news story (see Excerpt 3 ), the victims of the accident were identified either via the set of categorization relating to transportation ("passagers (passengers)", "membres de l'équipage (crew members)") or via the categorization of "survivants (survivors)". Consequently, "victimes (victims)" runs the risk of being interpreted as deceased persons rather than as the victims of an unfortunate event. Additionally, such an interpretation also clashes with the actions described in the account, namely rescuing and saving people. The journalist's suggestion of translating "victims" by "survivants (survivors)" (1.20) underlines this latter point. Nevertheless, the journalist eventually translates "victims" as "personnes (persons)," choosing a hypernym rather than translating "victims" by its possible antonym "survivants (survivors)".

As for the second categorization used to describe the persons being rescued by the security guard ("people"), the journalist first translates it as "personnes (persons)". Nevertheless, after having read his translation aloud, the journalist replaces "personnes (persons)" with "passagers (passengers)". The modification is most probably motivated by the proximity of "une trentaine de personnes (about thirty persons)" with "quatre personnes (four persons)" in this first version of the translation. In French, the repetition is often seen as a redundancy and thus devalued (Magri-Mourgues \& Rabatel, 2015, p.7). The journalist replaces "personnes (persons)" with a categorization already used in the TV news story: "passagers (passengers)". Once again, the journalist draws on the categorial resources already available in the news story to identify the characters (Hester, 2002; Stokoe \& Attenborough, 2015; Thornborrow \& Fitzgerald, 2004).

When it comes to solving the practical problems of characters' categorizations - either because the original categorization does not satisfy the logic of the event or because it is a question of avoiding the repetition of the same word at a short distance - the journalist turns to the categorizations already available in the co(n)text (i.e., the text of the TV news story he has already written). As a result, the adjustment of the characters' categorizations brings consistency between the perspective of the security guard on the events and that of the journalist. Such a 
phenomenon contributes not only to the textual coherence of the news story but also to homogenization of the tale world and, thus, its factuality.

\subsection{Consistency by the weakening of the events' sequencing}

The translation of the account weakens the events' sequencing while maintaining the description of the people being rescued. By doing so, the focus of attention seems to be more on the survivors than on the actions of their rescuer.

In the newswire, the first sentence ("I heard two explosions and I pulled four victims out of the plane and they were safe") depicts three moments, temporally articulated by a conjunction "and":

- an initial state ("I heard two explosions"), which motivates the subsequent action;

- a reaction ("I pulled four victims out of the plane"), motivated by the initial problematic state;

- $\quad$ an end state ("they were safe"), resulting from the agent's reaction after he perceived a problem.

However, this first sentence may also represent two moments. In that case, the third part of the sentence is interpreted as a description of the individuals to which the agent is providing assistance. This ambiguity causes a problem for the journalist during the translation (Excerpt 5).

(5) Weakening of the events' sequencing

(March 7, 2007, 11:28-11:29 a.m.)

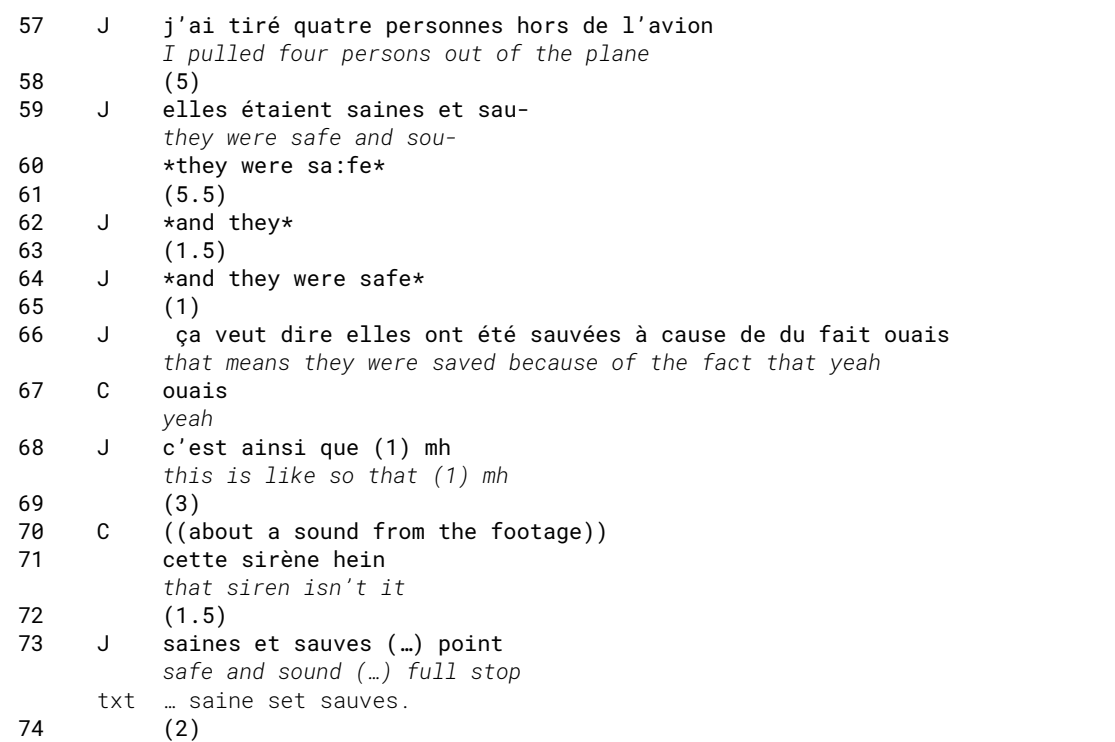


The journalist first brings to his attention the third part of the sentence only. He says "elles étaient saines et sau- (they were safe and sou-)" (1.59) and then repeats in English "they were safe" (1.60). After a few seconds of silence (1.61), the journalist's attention is no longer focused just on this part but also on its connection with the preceding part. It is indicated by the repetition of "and they" (1.62 and 64). It is confirmed when he wonders a second later about the causal relationship implied by this part: "that means they were saved because of the fact that yeah" (1.66). Although the journalist's turn at talk is incomplete, it is ratified by the cutter (1.67). In this context, it is likely that the missing complement of his turn could have been something like "because of the fact that he pulled them out of the aircraft". This leads him to interpret "they were safe" as a result of the previous action of the agent ("I pulled four victims out of the plane"). Additionally, "this is like so that" said by the journalist at line 68 supports such an interpretation, as it signals a causal link between the action of pulling people out of the plane and the state of being safe.

Nevertheless, without any further explanation, the journalist finally translates "and they were safe" with an extraposition ("saines et sauves (safe and sound)", 1.73). The extraposition emphasizes the fact of being safe more as a quality of the survivors than as the result of the agents' action. Thus, the journalist's wording weakens the events' sequencing without losing the survivors' description, which is the main focus of attention at this point of the TV news story. By doing so, the journalist seems to be acting cautiously, avoiding commenting on the causal relationship between two events. At the same time, he conducts his work skillfully, maintaining consistency regarding the beginning of the TV news story (see Excerpt 3).

\subsection{Consistency through the compression of time and place}

A last change enables the adjustment of the account to the news story: the translation of "were also gathered" as "se trouvaient déjà (were already)" (Excerpt 6). If "also" means a simultaneity or an addition relating to a first event, "déjà (already)" indicates the early development of an event.

(6) Excerpt 6: Compression of time and place

(March 7, 2007, 11:29-11:30 a.m.)

\begin{tabular}{|c|c|c|}
\hline 75 & $J$ & $\begin{array}{l}\text { trente } \\
\text { thirty }\end{array}$ \\
\hline 76 & & (4) \\
\hline 77 & $\mathrm{~J}$ & $\begin{array}{l}. h * \text { gathered* c'est }(.) \text { être à quai/ (.) } \\
. h * \text { gathered* it is (.) to be docked/ (.) }\end{array}$ \\
\hline 78 & & $\begin{array}{l}\text { hors de } l \text { 'appareil } \\
\text { out of the aircraft } \backslash\end{array}$ \\
\hline 79 & & $\begin{array}{l}\text { étaient rassemblés/ (..) hein/ [.tsk } \\
\text { were gathered/ (..) isn't it [.tsk }\end{array}$ \\
\hline 80 & C & $\begin{array}{l}\text { [euh rassemblé ouais }(\ldots) \text { ou } \\
\text { [er gathered yeah }(\ldots) \text { or }\end{array}$ \\
\hline 81 & $\mathrm{~J}$ & $\begin{array}{l}\text { euh environ } \\
\text { er around }\end{array}$ \\
\hline 82 & c & $\begin{array}{l}\text { ouais faut le voir large } \\
\text { yeah you have to see it on the generous side } \\
\text { environ }\end{array}$ \\
\hline
\end{tabular}




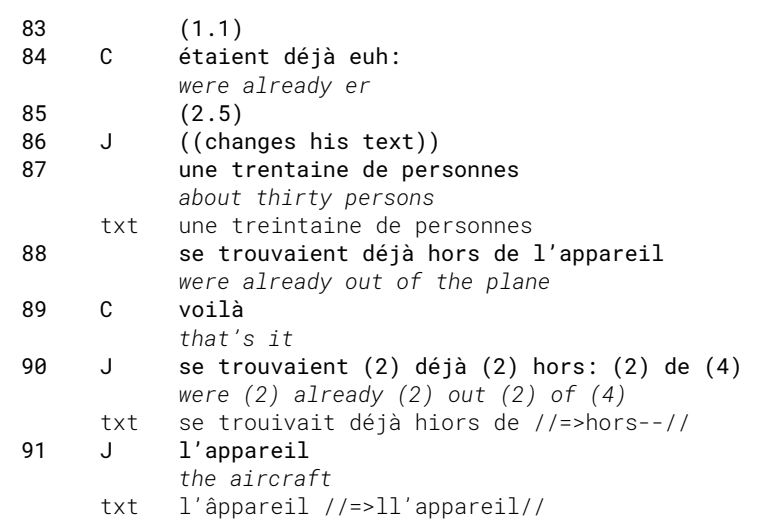

In Excerpt 6, the journalist is working on the second sentence of the newswire: "about 30 people were also gathered outside the plane". He suggests two ways of translating "were gathered" ("gathered c'est être à quai (gathered it is to be docked)", 1.77; "étaient rassemblés (were gathered)", 1.79), seeking the opinion of the cutter, who acknowledges the second suggestion (1.80). This second suggestion echoes dictionaries that usually cite rassembler as the common translation of to gather. However, the two practitioners eventually use another expression.

A few moment later, the cutter suggests translating "were also gathered" as "étaient déjà (were already)" (1.84). The journalist does not react (1.85) but then uses the expression "se trouvaient déjà (were already)," similar to "étaient déjà (were already)". This translation is supported directly by the cutter (1.89). This choice seems obvious to both practitioners. Yet the expression "se trouvaient déjà (were already)" suggests that the passengers were there before the agent's action while "were also gathered" indicates a simultaneous relationship between the events. This translation choice needs to be considered in light of what the journalist has written so far:

(7) Text of the news story at 11:29 (Journalist's computer, March 7, 2007, 11:29 a.m.) $<\ldots . . / /$ Quelques instants après le crash, la fuite éperdue loin du Boeing de l'un des survivants..ce passager n'est pas encore à l'abri mais sa caméra est enclenchée...//pas moins de 112 voyageurs sur les 133 transportés par la compagnie Garuda ont survécu, et six membres de l'équipage sur sept. Le témoignage d'un agent de sécurité de l’aéroport de Yogyakarta: "J’ai entendu deux explosions et j’ai tiré quatre personnes hors de l'avion... saine set sauves.

$<\ldots . . / /$ A few moments after the crash, the desperate escape far from the Boeing for one of the survivors..this passenger is not yet safe but his camera is on...//.no fewer than one hundred and twelve passengers among the one hundred and thirty-three transported by the Indonesian company Garuda survived, and six out of seven members of the crew. The account of a security guard at the airport in Yogyakarta: "I heard two explosions and I pulled four people out of the airplane ... safe and sound. 
In such a co(n)text, the expression "se trouvaient déjà (were already)" expresses the precedence of the depicted event over another one previously represented. It can be interpreted as a statement on how quickly the passengers were able to get out of the plane. It may, therefore, imply that the security guard took action in the immediate temporal surroundings of the accident. On the contrary, a description using rassembler (to gather) rather than se trouver déjà (to be already) could have appeared inconsistent in the light of the first sequence of the TV news story that depicts the surroundings of the aircraft as dangerous ("the desperate escape, far from the Boeing, for one of the survivors. This passenger is not yet safe," Excerpt 3).

In the newswire (Excerpt 2), the security guard's time of arrival on the crash site is unclear. As a result, there is room for more inferences. With respect to the news practitioners' interpretation of the events, the translation of "were also gathered" as "se trouvaient déjà (were already)" seems to be appropriate, even if "déjà (already)" adds information that the newswire version did not contain.

By doing so, the news practitioners situate the events recounted by the security guard in the (temporally) immediate surroundings of the crash, just like the events depicted at the beginning of the TV news story (Excerpt 3 ). The practitioners confine the space-time of the crash's consequences to its sole immediate surroundings. In fact, such a compression is at stake throughout the production of the news story (Merminod, 2019). News practitioners make narrative choices that enable them to remain on the crash scene: neither do they refer to Indonesia's recent history (natural disasters and repeated transportation accidents in the previous weeks) nor they address long-term or political impacts (illustrated by Australian and Indonesian official reactions to the crash). They delimit tellable chronotopes - "elaborate frames in which time, space, and patterns of agency coincide, create meaning and value" (Blommaert, 2015, p.110) - that enable them to orient themselves in the coverage of the news.

\section{Conclusion: The scope and limits of narrative adjustment}

The results of the analysis indicate that the processes of recontextualization affects the depiction of experience, event and chronotope in the account. Firstly, quoting involves the adjustment of the characters' categorizations to a set of categorizations favored by the media practitioners and thus leads to a homogenization of experience. Secondly, quoting entails choosing between different schemes of incidence, which sequences what happened slightly differently. Finally, quoting asks for a delimitation of the account's spatiotemporal parameters that corresponds with those of the TV news story. By working on the characters' categorizations, events' sequencings and on the spatiotemporal localization of the tale world, news 
practitioners make two different narrative configurations compatible. To do so, practitioners reduce, on the one hand, the divergences between the two narrative configurations, erasing what may appear contradictory or inconsistent. On the other hand, they take advantage of the convergences between both narratives as potentialities for adapting one configuration over the other. Thus, news practitioners consider the need to adjust discourse not only in relation to their audience (Bell, 1991, pp.104-125; Bell, 2001) but also in relation to the product they are making and in which the account will be integrated.

Such a narrative adjustment is neither a tightly planned nor an arbitrary process. It benefits from processes of recontextualization (the translation from English to French as well as the remediation from text to talk), and it is embedded in the professional activities as they unfold in the social and material world. In our data, for instance, the journalist makes the most of the presence of the cutter in the same room, by using a skillful three-step method to test his translation choices: reading an extract of the newswire aloud, suggesting a translation, and commenting on his translation. Nevertheless, news practitioners do not seem to make explicit the narrative nature of the adjustments they carry out. More likely, their choices result from a general orientation toward a given narrative configuration and a global interpretation of the events, which helps them to move toward consistency and coherence in spite of the inevitable heterogeneity of the stretches of text and talk they work with. Thus, far from being an uncertain way of performing their tasks, the way the practitioners carry out their daily work provides evidence of the existence of a narrative competence relating to a professional need to navigate between different versions of the same story. Yet a large part of this practical know-how remains tacit, calling for an ethnographic approach (Sarangi \& Candlin, 2010). This all the more so critical because journalists run the risk of being caught up in the stories they are telling, driven by the logic of a given narrative configuration rather than by the facts they have to report.

\section{Funding}

This work was supported by a grant from the Swiss National Science Foundation (P1LAP1_164898).

\section{Acknowledgements}

I am grateful to Lauri Haapanen, Daniel Perrin, Ben Rampton and the anonymous reviewers for their support and their helpful suggestions. All caveat apply. 


\section{References}

Bauman, R., \& Briggs, C. (1990). Poetics and performance as critical perspectives on language and social life. Annual Review of Anthropology, 19, 59-88. https://doi.org/10.1146/annurev.an.19.100190.000423

Bell, A. (1991). The language of news media. Oxford: Blackwell.

Bell, A. (2001). Back in style: Re-working audience design. In P. Eckert \& J. Rickford (Eds.), Style and sociolinguistic variation (pp. 139-169). Cambridge: Cambridge University Press.

Blommaert, J. (2015). Chronotopes, scales and complexity in the study of language in society. Annual Review of Anthropology, 44, 105-116. https://doi.org/10.1146/annurev-anthro-102214-014035

Burger, M. (Ed.). (2018). Investigating journalism practices: Combining media discourse analysis and newsroom ethnography. Lausanne: CLSL.

Cotter, C. (2010). News talk. Investigating the language of journalism. Cambridge: Cambridge University Press. https://doi.org/10.1017/CBO9780511811975

Davier, L. (2017). Les enjeux de la traduction dans les agences de presse. Lille: Presses universitaires du Septentrion. https://doi.org/10.4000/books.septentrion.31795

Davier, L., \& Coway, K. (Eds.). (2019). Journalism and translation in the era of convergence. Amsterdam: John Benjamins. https://doi.org/10.1075/btl.146

Fludernik, M. (2009). An introduction to narratology. London: Routledge. https://doi.org/10.4324/9780203882887

Georgakopoulou, A. (2007). Small stories, interaction and identities. Amsterdam: John Benjamins. https://doi.org/10.1075/sin.8

Georgakopoulou, A. (2015). Small stories research: Methods-analysis-outreach. In A. De Fina \& A. Georgakopoulou (Eds.), The handbook of narrative analysis (pp. 255-271). Oxford: Wiley-Blackwell.

Haapanen, L. (2017). Directly from interview to quotations? Quoting practices in written journalism. In R. Laury, M. Etelämäki, Marja, \& E. Couper-Kuhlen (Eds.), Combining clauses and actions in social interaction. Helsinki: Suomalaisen Kirjallisuuden Seura.

Haapanen, L. (2018). Rethinking quoting in written journalism: An intertextual chain from an interview into quotations. Cahiers de l'Institut de Linguistique et des Sciences du Langage, 54, 95-118.

Haapanen, L., \& Perrin, D. (2017). Media and quoting. Understanding the purposes, roles, and processes of quoting in mass and social media. In C. Cotter \& D. Perrin (Eds.), The Routledge handbook of language and media (pp. 424-441). London: Routlegde. https://doi.org/10.4324/9781315673134-31

Haapanen, L., \& Perrin, D. (2019). Translingual quoting in journalism: Behind the scenes of Swiss television newsrooms. In L. Davier \& K. Coway (Eds.), Journalism and translation in the era of convergence (pp. 15-42). Amsterdam: John Benjamins. https://doi.org/10.1075/btl.146.01haa

Herman, D. (2009). Basic elements of narrative. Oxford: Wiley-Blackwell. https://doi.org/10.1002/9781444305920

Hester, S. (2002). Bringing it all back home: Selecting topic, category and location in TV news programmes. In S. Hester, \& W. Housley (Eds.), Language, interaction and national identity: Studies in the social organisation of national identity in talk-in-interaction (pp. 16-37). Aldershot: Ashgate. 
Jacobs, G. (2017). Organizations and corporate communication. Linguistic ethnography in the newsroom. In C. Cotter, \& D. Perrin (Eds.), The Routledge handbook of language and media (pp. 178-189). London: Routlegde. https://doi.org/10.4324/9781315673134-14

Magri-Mourgues, V., \& Rabatel, A. (2015). Quand la répétition se fait figure. Semen, 38, 7-13.

Merminod, G. (2020). Situations et idéologies narratives en salle de rédaction. Ce que les petites histoires disent de la façon de raconter des journalistes. In S. Patron (Ed.), Small stories. Un nouveau paradigme pour la recherche sur le récit. Paris: Hermann.

Merminod, G. (2019). Histoire d'une nouvelle. Pratiques narratives en salle de rédaction. Bruxelles: De Boeck.

Merminod, G. (2018a). Saying 'story' in the newsroom. Towards a linguistic ethnography of narrative lexicon in broadcast news. Studies in Communication Sciences, 18(1), 135-150. https://doi.org/10.24434/j.scoms.2018.01.010

Merminod, G. (2018b). Telling stories from the newsroom: A linguistic ethnographic account of dramatization in broadcast news. Cahiers de l'Institut de Linguistique et des Sciences $d u$ Langage, 54, 25-54.

Merminod, G., \& Burger, M. (2020). Narrative of vicarious experience in broadcast news. Journal of Pragmatics, 155, 240-260. https://doi.org/10.1016/j.pragma.2019.09.001

News Text \& Talk Research Group. (2011). Towards a linguistics of news production. Journal of Pragmatics, 43(7), 1843-1852. https://doi.org/10.1016/j.pragma.2010.09.022

Norrick, N. R. (2004). The dark side of tellability. Narrative Inquiry, 15(2), 323-343. https://doi.org/10.1075/ni.15.2.07nor

Perrin, D. (2013). The linguistics of newswriting. Amsterdam: John Benjamins. https://doi.org/10.1075/aals.11

Perrin, D. (2018). On, for, and with practitioners. A transdisciplinary approach to text production in real-life settings. AILA Review, 31, 53-80. https://doi.org/10.1075/aila.00013.per

Sarangi, S., \& Candlin, C.N. (2010). Applied linguistics and professional practice: Mapping a future agenda. Journal of Applied Linguistics and Professional Practice, 7(1), 1-9. https://doi.org/10.1558/japl.v7i1.1

Stokoe, E., \& Attenborough, F. (2015). Prospective and retrospective categorization. Category proffers and inferences in social interaction and rolling news media. In R. Fitzgerald \& W. Housley (Eds.), Advances in membership categorisation analysis (pp. 51-70). London: Sage. https://doi.org/10.4135/9781473917873.n3

Rampton, B., Maybin, J., \& Roberts, C. (2015). Theory and method in linguistic ethnography (2015). In J. Snell, S. Shaw, \& F. Copland (Eds.), Linguistic ethnography. Interdisciplinary explorations (pp. 14-50). New York, NY: Palgrave McMillan. https://doi.org/10.1057/9781137035035_2

Riegel, M., Pellat, J.-C., \& Rioul, R. (2014). Grammaire méthodique du français. Paris: Presses Universitaires de France.

Thornborrow, J., \& Coates, J. (Eds.). (2005). The sociolinguistics of narrative. Amsterdam: John Benjamins. https://doi.org/10.1075/sin.6

Thornborrow, J., \& Fitzgerald, R. (2004). Storying the news through category, action, and reason. The Communication Review, 7(4), 345-352. https://doi.org/10.1080/10714420490886943 
Van Hout, T. (2015). Between text and social practice: Balancing linguistics and ethnography in journalism studies. In J. Snell, S. Shaw, \& F. Copland (Eds.), Linguistic ethnography. Interdisciplinary explorations (pp. 71-89). New York, NY: Palgrave McMillan. https://doi.org/10.1057/9781137035035_4

Van Hout, T., \& Jacobs, G. (2008). News production theory and practice: Fieldwork notes on power, interaction and agency. Pragmatics, 18(1), 59-85. https://doi.org/10.1075/prag.18.1.04hou

Van Hout, T., \& Macgilchrist, F. (2010). Framing the news: An ethnographic view of business newswriting. Text \& Talk, 30(2), 169-191. https://doi.org/10.1515/text.2010.009

\title{
Address for correspondence
}

\author{
Gilles Merminod \\ University of Lausanne \\ Gilles Merminod, Anthropole 3143, Quartier UNIL-Chamberonne \\ $\mathrm{CH}-1015$ Lausanne \\ Switzerland \\ gilles.merminod@unil.ch
}

